\title{
Analisis biomotor kecepatan reaksi pada pemain bola voli kelas khusus olahraga Daerah Istimewa Yogyakarta
}

\author{
Fauzi *, Riky Dwihandaka, Okky Indera Pamungkas, Muhamad Nanang Solikhin \\ Universitas Negeri Yogyakarta. Jl Colombo No.1, Yogyakarta 55281, Indonesia \\ * Coressponding Author. E-mail: fauzi@uny.ac.id
}

Received: June 24, 2021 ; Accepted: September 7, 2021 ; Published: September 25, 2021

\begin{abstract}
Abstrak: Empat puluh tiga pemain yang berlatih di Sekolah Menengah Atas Kelas Khusus Olahraga Daerah Istimewa Yogyakarta berpartisipasi dalam penelitian ini. Pengambilan data telah disetujui oleh pelatih dari sekolah tersebut. Para pemain dalam kondisi sehat saat melakukan tes. Sebelum melakukan tes, pemain mendapatkan penjelasan tentang penelitian ini. Instrumen yang dipergunakan dalam pengambilan data untuk mengetahui kecepatan reaksi seseorang diukur dengan menggunakan tes whole body reaction. Setelah data diperoleh kemudian dianalisis dengan membandingkan data dengan norma instrument tes whole body reaction. Kemudian setelah itu dicari prosentase kategori kecepatan reaksi yang dimiliki oleh pemain Kelas Khusus Olahraga Bola Voli di D.I. Yogyakarta. Dari hasil pengukuran yang dilakukan ditemukan bahwa terdapat 30\% dari pemain bola voli di Kelas Khusus Olahraga Yogyakarta memiliki kecepatan reaksi yang masuk dalam kategori bagus sekali, 63\% termasuk dalam kategori bagus, dan 7\% dalam kategori cukup. Hasil ini tentu tidak akan terlepas dari banyak faktor yang mempengaruhi kecepatan reaksi yang dimiliki oleh seseorang.
\end{abstract}

Kata Kunci: biomotor, kecepatan reaksi, bola voli, KKO

\section{Biomotor analysis of reaction speed in players of special class volleyball in Yogyakarta Special Region}

\begin{abstract}
Forty-three players who trained at the Yogyakarta Special Sports Class High School participated in the study. The data retrieval has been approved by the school's trainer. The players are in good health when conducting tests. Before conducting the test, the player gets an explanation about this study. The instrument used in data retrieval to determine the speed of a person's reaction is measured using the Whole Body Reaction test. After the data is obtained then analyzed by comparing the data with the instrument norms of whole body reaction test. Then after that sought percentage of reaction speed category owned by player of special class volleyball sports in D.I. Yogyakarta. From the results of the measurements, it was found that $30 \%$ of volleyball players in Yogyakarta Sports Special Class had reaction speed that falls into the category of very good, $63 \%$ belongs to the good category, and $7 \%$ in the category of enough. These results will certainly not be separated from many factors that affect the speed of reaction that a person has.
\end{abstract}

Keywords: Biomotor, speed reaction, volley ball, special sports class.

How to Cite: Fauzi, F., Dwihandika, R., Pamungkas, O. I, \& Solikhin, M. N. (2021). Analisis biomotor kecepatan reaksi pada pemain bola voli kelas khusus olahraga Daerah Istimewa Yogyakarta. Jurnal Keolahragaan, 9 (2), 246-255. doi: https://doi.org/10.21831/jk.v9i2.41704

\section{PENDAHULUAN}

Olahraga terbagi dalam berbagai macam cabang, baik olahraga individu, tim, ataupun juga permainan. Setiap olahraga memiliki karakteristik yang berbeda, akan tetapi, semua cabang olahraga sangat ditentukan oleh faktor-faktor yang memiliki pengaruh baik bersifat dari dalam tubuh seorang atlet (intrinsic) maupun yang berasal dari luar tubuh atlet (ekstrinsic). Beberapa faktor yang ada berasal dari dalam diri atlet adahal teknik, taktik, mental, biomotor (fisik), psikomotor, anthropometri, genetika, dan lain-lain. Sedangkan faktor yang berasal dari luar tubuh atlet diantaranya adalah faktor motivasi, gizi, dan lain-lain.

Perilaku atau kontrol tubuh seseorang biasa disebut dengan domain psikomotor, sedangkan untuk kapasitas kerja fisik seseorang biasa disebut dengan biomotor. Kedua domain nini sebenarnya tidak bisa 
dipisahkan dari perbedaan yang ada karena sebenarnya domain bimotor dan psikomotor memiliki fungsi kerja bersama-sama. Kemampuan biomotor berkaitan dengan kemampuan gerak yang dimiliki oleh seseorang tetapi juga pada dasarnya dipengaruhi oleh berbagai sistem organ manusia seperti sistem pencernaan, pernapasan, tulang dan persendian, peredaran darah, ataupun sistem saraf (neuromuskuler). Berbagai cabang olahraga yang ada tentu akan didukung dan juga mendapat kemudahan dalam proses gerak oleh kualitas biomotor yang baik.

Salah satu komponen biomotor yang memiliki peranan penting adalah kecepatan reaksi. Waktu antara diterimanya stimulus dan munculnya respon yang sesuai oleh seseorang dalam waktu sesingkat mungkin biasa diebut dengan kecepatan reaksi. Kecepatan reaksi ini merupakan kemmapuan fungsi sensorimotor yang dimiliki oleh individu yang melibatkan pemrosesan stimulus, pengambilan keputusan, dan pemrograman respon (Gandhi et al., 2013). Keterlibatan saraf pusat yang mengenali sebuah stimulus atau rangsangan kemudian melanjutkan ke otot untuk melakukan tindakan merupakan sistem dalam kecepatan reaksi. Neuron sensorik yang mendeteksi stimulus kemudian akan mengirimkan pesan tentang stimulus ke otak atau tulang belakang, yang menafsirkan informasi dan memutuskan beberapa jenis tindakan. Sebuah pesan kemudian dibawa kembali ke sel neuron motorik. Sel neuron motorik mengarahkan otot untuk melakukan respon. Semua aktivitas ini dalam sistem saraf terjadi dalam sepersekian detik. Sepersekian detik itu diukur sebagai waktu reaksi.

Visual Reaction Time (VRT) dikenal sebagai Waktu yang dibutuhkan untuk merespon rangsangan visual. Penerimaan stimulus dan juga pemograman respon merupakan tolak ukur penting bagi pemrosesan informasi dalam kecepatan reaksi (Rao et al., 1985). Terdapat tiga jenis waktu reaksi.1) Simple reaction time: terdapat satu stimulus dan satu respons. 2) Recognition reaction time: stimulus yang harus direspons dan lainnya yang tidak mendapatkan respons. 3) Choice reaction time: terdapat beberapa stimulus dan beberapa respons (Luce, 2008). Dengan latihan yang melibarkan gerakan motorik, koordinasi otot dan kecepatan gerak dapat ditingkatkan sehingga akan meningkatkan kecepatan reaksi. Peningkatan jangka panjang dalam melakukan gerakan gerakan terampil dapat dicapai dengan berlatih dan melakukan gerak yang diulang secara terus menerus (Agostino et al., 2004).

Pencapaian seseorang di banyak bidang seperti, olahraga, akademisi, musik, tari, dll dapat meningkat jika seseorang memiliki waktu raksi yang lebih pendek karena seberapa cepat seseorang merespons stimulus tertentu menjadi ukuran dalam kecepatan reaksi. Dengan mengidentifikasi waktu reaksi orang tersebut, kita dapat memprediksi kemampuan bereaksi dalam menghadapi situasi tertentu.

Didalam dunia olahraga, kecepatan reaksi menjadi sangat penting karena untuk mengembangkan gerakan tertentu dan juga motorik halus yang dimiliki oleh atlet. Banyak faktor yang bisa meningkatkan kecepatan reaksi seperti konsentrasi dan kesabaran, koordinasi otot yang lebih baik, dan peningkatan kinerja dalam kecepatan. Reaksi yang cepat sangat membantu dalam olahraga seperti sepak bola, bola basket, dan tenis (Proctor \& Dutta, 1995). Beberapa penelitian juga telah menemukan bahwa pada program olahraga yang disusun secara teratur dapat meningkatkan kekuatan otot dan ini membantu peningkatan signifikan dalam kecepatan reaksi (Guadagnoll \& Lee, 2004; Luce, 2008).

Pemain yang memiliki kecepatan reaksi yang lebih singkat dan antisipasi yang lebih akurat akan memiliki keuntungan yang lebih tinggi dalam performanya di dalam olahraga bola voli. Beberapa penelitian menunjukkan pentingnya kecepatan reaksi di beberapa olahraga seperti sepak bola (Kim et al., 2014; Saygin et al., 2016), bola basket (Abreu et al., 2012; Fujii et al., 2014), bola tangan (GutierrezDavila et al., 2011; Loffing \& Hagemann, 2014), tenis dan tenis meja (Akpinar et al., 2012; Emre \& Koçak, 2010), bulu tangkis (Gülaç et al., 2017), bisbol dan rugby (Connor et al., 2018; Nakamoto \& Mori, 2012) dan karate (Mori et al., 2002). Beberapa penelitian juga menunjukkan pentingnya kecepetan reaksi dalam bola voli (Nuri et al., 2013; Piras et al., 2014). Terdapat penelitian yang menunjukkan adanya pengaruh perbedaan posisi dalam permainan bola voli dan juga kecepatan reaksi. Dalam permainan bola voli, pemain tengah memiliki kombinasi serangan dari banyak arah dan tanggung jawab blok (Millán-Sánchez et al., 2019). Para pemain bola voli melaporkan bahwa orientasi dan posisi terhadap bola yang akan dipukul, yang muncul sesaat sebelum kontak bola tangan adalah isyarat penting dalam mengantisipasi jalur serangan (Takeyama, T., Hirose, N., \& Mori, 2011). Kemampuan untuk mendeteksi objek bergerak dan akurasi prediksi pemain bola voli profesional ditemukan lebih tinggi dibandingkan dengan pemain bola voli pemula(Schorer et al., 2013). Pemain bola voli profesional tampil lebih baik dalam kecepatan persepsi, perhatian terfokus, prediksi, dan perkiraan kecepatan dan arah benda bergerak (Kioumourtzoglou et al., 1998). Dalam sebuah penelitian, ditunjukkan bahwa pemain bola voli memprediksi kecepatan dan timing bola lebih baik daripada pelari cepat (Nuri et al., 2013). 
Alasannya adalah karena pemain bola voli berlatih dalam lingkungan yang dinamis di mana mereka terus-menerus memprediksi di mana bola akan berada. Oleh karena itu, kemampuan antisipasi dan memprediksi bola para pemain bola voli akan selsalu lebih ditingkatkan. Zhou (Zhou, 2018) menyatakan bahwa pemain bola voli yang bermain dalam posisi yang berbeda akan menggunakan strategi menerima respon yang berbeda, mereka menemukan bahwa kelompok penyerang menggunakan waktu lebih singkat untuk melihat bola, dan akurasi prediksi dan respon juga lebih tinggi dibandingkan posisi bermain lainnya.

Waktu reaksi dalam bola voli memberikan pemahaman yang lebih baik tentang permainan dan mengarah pada respons yang lebih cepat terhadap tindakan apa yang harus dilakukan (Lotério Barcelos et al., 2009). Waktu reaksi terhadap rangsangan yang muncul pada penglihatan pusat dan perifer yang dimiliki pemain bola voli (usia rata-rata: 22,86 $\pm 2,09$ tahun) lebih baik dibandingkan dengan non-atlet (Zwierko et al., 2010). Hal ini dikaitkan dengan adaptasi struktural dan fungsional dalam sistem saraf pusat. Selain itu, kinerja reaksi visuomotor untuk atlet yang tampil pada tingkat keterampilan tinggi dipengaruhi oleh proses visual dan karakteristik struktural dan fungsional dari area mid-temporal yang peka terhadap gerakan visual (Hülsdünker et al., 2018). Waktu reaksi pemain bola voli yang bermain di posisi berbeda telah dibandingkan dan menunjukkan hasil yang berbeda (Lotério Barcelos et al., 2009). Mereka mengamati bahwa waktu reaksi penyerang tengah dan penyerang sisi kuat ditemukan memiliki waktu reaksi yang lebih cepat karena karakteristik pergerakan posisi bermain mereka. Mereka juga mengungkapkan bahwa alasan mengapa para pemain tengah berkinerja lebih baik pada tes waktu reaksi terkait dengan karakteristik fungsional para pemain.

Melihat pentingnya kecepatan reaksi dalam permainan bola voli. Analisis terhadap kecepatan reaksi pada pemain bola voli tentu sangat dibutuhkan untuk menunjang perkembangan yang dimiliki pemain. Pada proses latihan di Kelas Khusus Olahraga bola voli DIY, masih sering ditemukan kesalahan mendasar yang dilakukan oleh pemain dalam melakukan antisipasi maupun keputusan gerak yang diambil. Hal ini tentu saja dipengaruhi oleh kecepatan reaksi yang dimiliki. Berkenaan dengan hal tersebut dan untuk menunjang dan meningkatkan performa dan proses latihan maka peneliti ingin mengetahui dan menganalisis kecepatan reaksi yang dimiliki oleh pemain bola voli Kelas Khusus Olahraga bola voly di Dareah Istimewa Yogyakarta.

\section{METODE}

Jenis penelitian yang digunakan dalam penelitian ini adalah deskriptif kuantitatif. Metode yang digunakan yaitu dengan menggunakan tes kecepatan reaksi. Arikunto (Suharsimi, 2013) menyatakan bahwa dalam penelitian deskriptif pengujian hipotesis tertentu bukan menjadi maksud utama, tetapi digunakan untuk menjelaskan tentang kondisi suatu variabel yang ada. Kecepatan reaksi dari empat puluh tiga pemain yang berlatih di Sekolah Menengah Atas Kelas Khusus Olahraga Daerah Istimewa Yogyakarta akan dijelaskan dalam hasil penelitian ini.

Sampel penelitain yang digunakan berjumlah empat puluh tiga pemain yang berlatih di Sekolah Menengah Atas Kelas Khusus Olahraga Daerah Istimewa Yogyakarta. Pengambilan data telah disetujui oleh pelatih dari sekolah tersebut. Para pemain dalam kondisi sehat saat melakukan tes. Sebelum melakukan tes, pemain mendapatkan penjelassan tentang penelitian ini.

Instrumen yang dipergunakan dalam pengambilan data untuk mengetahui kecepatan reaksi seseorang diukur dengan menggunakan tes Whole Body Reaction (Fananlampir, 2015). Pelaksanaan tes dimulai dengan subyek berdiri di atas matras atau alas tumpu yang terbuat dari karet dan di dalamnya terdapat sensor dengan posisi kaki menekuk sedikit lututnya agar tidak menjadi hambatan ketika bereaksi setelah stimulus diberikan. Kemudian Ketika tester menekan tombol, maka akan keluar stimulus berupa cahaya. Setelah itu testi secepatnya melakukan reaksi dengan membuka kedua kaki atau mengeluarkan kedua kaki dari alas tumpu. Angka yang tertera pada display adalah angka ketika testi menjawab rangsang menunjukan waktu reaksinya. Waktu reaksi yang tercepat yang di gunakan untuk menilai waktu reaksi testi merupakan waktu yang digunakan dalam penilaian. Instrument dalam peneltian ini adalah Whole body reaction untuk mengukur kecepatan reaksi dengan koofesien realibilitas $(0,93)$ dan validitas $(0,607)$ dalam buku Tes dan Pengukuran Keolahragaan (Nurhasan, 2007). 
Setelah data diperoleh kemudian dianalisis dengan membandingkan data dengan norma instrument tes Whole body reaction. Kemudian setelah itu dicari prosentase kategori kecepatan reaksi yang dimiliki oleh pemain KKO Bola Voli di D.I. Yogyakarta dengan cara sebagai berikut :

$$
\frac{\text { Jumlah pemain yang masuk dalam kategori }}{\text { Jumlah pemain keseluruhan }} \times 100 \%
$$

\section{HASIL DAN PEMBAHASAN}

\section{Hasil}

Data yang diperoleh setelah dilakukan tes Whole body reaction pada pemain Kelas Khusus Olahraga Bola Voli di D.I. Yogyakarta adalah sebagai berikut:

Tabel. 1. Hasil Tes Whole Body Reaction Kelas Khusus Olahraga Bola Voli

\begin{tabular}{ccc}
\hline No & Hasil Test & n \\
\hline 1 & 0,12 & 1 \\
2 & 0,18 & 12 \\
3 & 0,24 & 21 \\
4 & 0,30 & 6 \\
5 & 0,36 & 3 \\
\hline Rata-rata & $\mathbf{0 , 2 4}$ & \\
\hline Jumlah & & $\mathbf{4 3}$ \\
\hline
\end{tabular}

Sedangkan norma whole body reaction time test sebagai berikut (Miyatake, 2012):

Tabel 2. Norma Whole Body Reaction Time Test

\begin{tabular}{lll}
\hline No & Angka dalam detik & Kriteria \\
\hline 1 & $0.001-0.100$ & Istimewa \\
2 & $0.101-0.200$ & Bagus Sekali \\
3 & $0.201-0.300$ & Bagus \\
4 & $0.301-0.400$ & Cukup/Sedang \\
5 & $0.401-0.500$ & Kurang \\
6 & $0.501>$ & Kurang Sekali \\
\hline
\end{tabular}

Setelah dilakukan pengukuran kecepatan reaksi pada pemain Kelas Khusus Olahraga bolavoli Daerah Istimewa Yogyakarta, didapatlah data pelaksanaan diambil mengguankan Whole Body Reaction Test. Berikut data yang telah dianalisis dan dipresentasekan berdasarkan kriteria norma Whole Body Reaction Test:

Tabel 3. Persentase Kriteria Norma Whole Body Reaction

\begin{tabular}{cccc}
\hline No & Kriteria & Jumlah pemain & Presentase (\%) \\
\hline 1. & Bagus Sekali & 13 & 30 \\
2. & Bagus & 27 & 63 \\
3. & Cukup & 3 & 7 \\
\hline & Jumlah & 43 & 100 \\
\hline
\end{tabular}


Jurnal Keolahragaan 9 (2), 2021 - 250

Fauzi, Riky Dwihandaka, Okky Indera Pamungkas, Muhamad Nanang Solikhin

Kemudian berikut presentase dalam bentuk diagram:

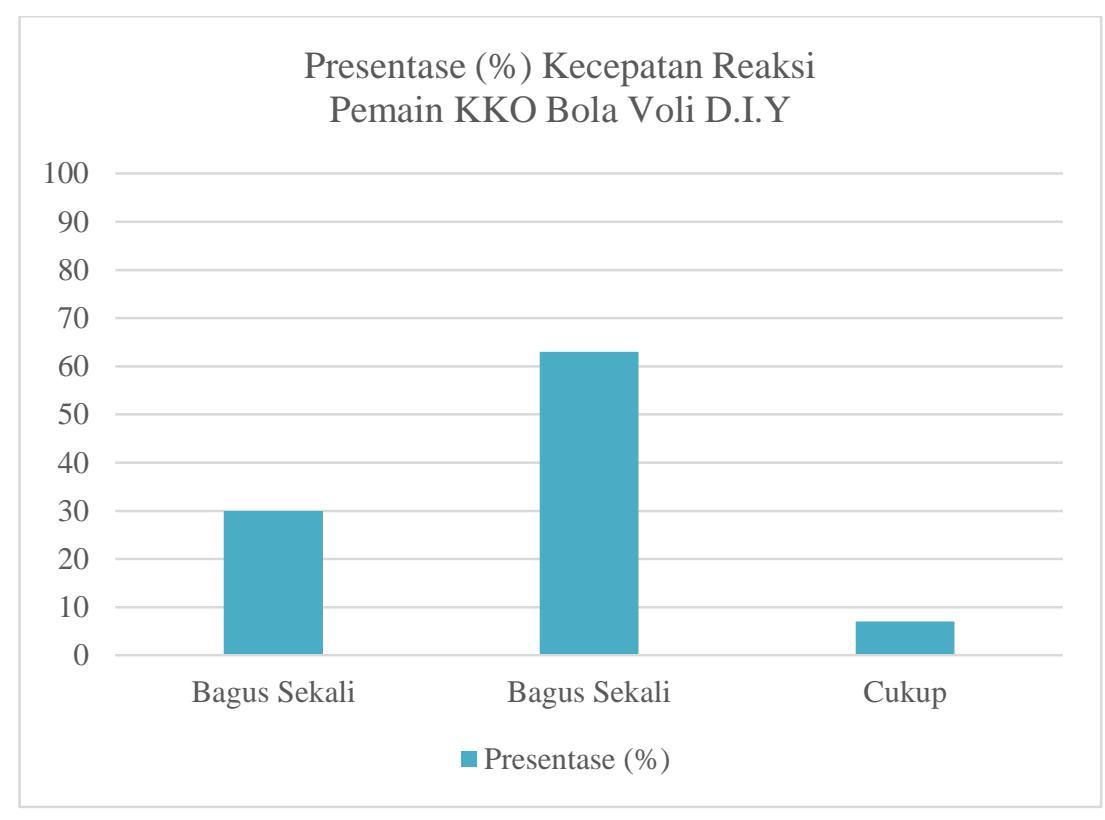

Gambar 1. Persentase Kecepatan Reaksi Pemain Kelas Khusus Olahraga Bola Voli DIY

\section{Pembahasan}

Kecepatan reaksi sering diartikan waktu yang dibutuhkan oleh seseorang dari mendapatkan stimulus dan kemudian mampu bereaksi terhadap stimulus tersebut. Kecepatan reaksi ini merupakan indicator yang reliable untuk mengukur pemrosesan stimulus oleh Sistem saraf pusat dan kemudian akan direspon oleh alat gerak. Semakin cepat seseorang merespon stimulus dalam kecepatan reaksi ini menjadi hal yang menentukan kesiapan seseorang (Solanki et al., 2012).

Waktu yang dibutuhkan dalam memproses stimulus yang datang dan kemudian direspon menjadi gerak bersifat individual, setiap orang memiliki waktu yang berbeda-beda. Waktu atau interval yang dibutuhkan ini sebenarnya menempuh 3 tahap. Tahap pertama adalah penerimaan stimulus atau rangsangan, kemudian yang kedua adalah pemrosesan dari stimulus yang datang, tahap ketiga adalah pemrograman kembali stimulus menjadi respon. Di samping itu, pengukuran kecepatan reaksi meliputi beberapa hal, pertama adalah bagaimana sistem saraf mampu mengubah stimulus menjadi kode yang melewati jalur pusat dan perifer. Yang kedua adalah pemrosesan kognitif dan perspektif, yang ketiga adalah pengubahan kode yang sudah diproses menjadi sinyal gerak yang melewati jalur pusat dan perifer, dan kemudian diaktifasi menjadi gerak yang dilakukan oleh alat gerak (Botwinick \& Thompson, 1966). Kualitas kecepatan dalam pemrosesan informasi yang dimiliki oleh seseorang dapat dievaluasi melalui satu atau lebih stimulus, kemudian juga dapat diukur dari bagaimana perspektif motoric yang dilakukan. Kedua proses tersebut adalah pengukuran yang sesuai untuk kecepatan reaksi. Akan tetapi, dengan memberikan lebih dari satu stimulus tentu akan memberikan tekanan yang lebih besar dibandingkan dengan hanya diberikan satu stimulus (Maciel et al., 2009).

Waktu reaksi merupakan salah satu indikator yang paling banyak digunakan sebagai alat ukur kemampuan motorik yang dibutuhkan untuk latihan olahraga. Pemain yang memiliki kecepatan reaksi yang lebih singkat dan antisipasi yang lebih akurat akan memiliki keuntungan yang lebih tinggi dalam performanya di dalam olahraga bola voli. Beberapa penelitian menunjukkan pentingnya kecepatan reaksi di beberapa olahraga seperti. Dalam karakteristik bola voli, tentu akan sangat menarik untuk memiliki mekanisme dalam memproses respon dengan sangat cepat. Dari hasil pengukuran yang dilakukan ditemukan bahwa terdapat $30 \%$ dari pemain bola voli di KKO Yograkarta memiliki kecepatan reaksi yang masuk dalam kategori bagus sekali, 63\% termasuk dalam kategori bagus, dan 7\% dalam kategori cukup. Hasil ini tentu tidak akan terlepas dari banyak faktor yang mempengaruhi kecepatan reaksi yang dimiliki oleh seseorang. Usia, jenis kelamin, tangan yang dominan, sistem saraf, latihan, kelelahan, pola makan, personalia merupakan beberapa faktor yang mem.pengaruhi kecepatan reaksi (Bamne et al., 2011). Beberapa penelitian lain juga menyebutkan faktor-faktor yang mempengaruhi 
seperti caffeine dan obat (Spencer et al., 2009), penyakit (Smith et al., 2004), status ekonomi dan pola hidup yang biasa dilakukan (Moradi \& Esmaeilzadeh, 2015). Ada juga keterkaitan antara faktor berat badan terhadap kecepatan reaksi yang dimiliki seseorang (Kamijo et al., 2014).

Kecepatan reaksi juga ditemukan berbeda pada atlet dan non atlet, bahwa atlet memiliki kecepatan dalam mencari dan menemukan stimulus dalam visual kecepatan reaksi (Akarsu et al., 2009). Hal ini menunjukkan bahwa tingkat keterlatihan seseorang tentu memiliki pengaruh terhadap kecepatan reaksi.

Seseorang yang terlatih yang memiliki kecepatan reaksi lebih cepat dibandingkan dengan seseorang yang tidak terlatih terletak pada bagaimana kesiapan dan konsentrasi yang mereka miliki dan koordinasi otot yang berhubungan dengan kecepatan gerak yang lebih cepat. Bagaimanapun juga, orang yang memiliki keterlatihan yang lebih baik akan memiliki keuntungan mampu bergerak lebih cepat dan sesuai kebutuhan di cabang olahraga masing-masing karena memiliki kecepatan reaksi yang baik pula (Gavkare, 2013).

Penelitian lain juga menyebutkan hipotesis teori yang disebut dengan physchomotor theory, disebutkan bahwa ada hubungan antara latihan dan juga kontrol pikiran, dimana seseorang mampu melakukan gerak tubuh yang sesuai dengan apa yang diinginkan (Tan, 2007), atau juga bisa disebut dengan kecerdasan kinestetik tubuh (Gardner \& Hatch, 1989), kemampuan gerak dari pemikiran (Fischer \& Bidell, 1998). Selain itu, ketika seseorang melakukan latihan olahraga, terdapat juga efek berupa penenang atau anti depresan yang mampu lebih meningkatkan performa kinerja seseorang tersebut (Rojas-Valverde, 2021). Bahkan penelitian yang dilakukan oleh Tan (Tan, 2007) mengemukakan bahwa dalam kemampuan kognitif, kemampuan gerak seseorang dapat menempatkan posisi yang penting.

Secara lebih lanjut, hal-hal diatas menujukkan manfaat latihan yang diperoleh untuk mampu meningakatkan kecepatan reaksi secara visual. Tidak ada juga perbedaan yang ditunjukkan dari berbagai macam olahraga seperti sepak bola, bola basket, bola voli, lari, dan permainan ski (Tomporowski, 2003). Permainan tenis meja juga memerlukan kecepatan reaksi yang baik karena hal itu merupakan unsur potensi gerak yang sangat mendukung permainan (Atmaja \& Tomoliyus, 2015). Kecepatan reaksi juga menjadi salah satu biomotor penting yang diperlukan oleh pemain bulu tangkis disemping biomotor lain seperti kecepatan, power, kelentukan, daya tahan dan kelincahan (Zhannisa \& Sugiyanto, 2015). Oleh karena itu, dalam voli, pemain yang dibutuhkan oleh tim tampaknya adalah pemain yang memiliki kecepatan reaksi yang tinggi, yang mampu melakukan gerakan dan karakteristik dari fungsi sistem saraf yang efisien.

Kecepatan reaksi tentu juga akan berguna untuk memaksimalkan teknik yang dimiliki dalam permainan bola voli. Seorang atlet ketika memiliki kecepetan reaksi yang bagus bisa ditanyai bagaimana dia bisa menerima bola dengan baik sebagai awalan untuk melanjutkan serangan oleh satu tim. Selain itu, atlet bola voli yang memiliki kecepatan reaksi yang bagus juga memungkinkan untuk bisa melakukan smash dengan mudah, hal ini dikarenakan dia bisa mengolah stimulus ang dapat baik sebelum memukul bola maupun sesudah memukul bola. Kecepatan reaksi yang kurang dimiliki atlet untuk melakukan smash makan smash yang dihasilkan juga kurang maksimal. Diperlukan latihan dan kecepatan reaksi yang bagus dalam melakukan smash yang baik. Pentingnya kecepatan reaksi dalam teknik smash tentu saja akan diperlukan dalam melakukan teknik yang lain seperti passing, bloking, dan lain-lain. Selain kecepatan reaksi juga terdapat korelasi antara koordinasi mata tangan dan kecepatan reaksi sehingga pemain dapat melakukan smash dengan baik (Nasriani \& Mardela, 2019).

Melihat dari data yang diperoleh memang presentase pemain yang berada di kategori bagus sudah mencapai 63\%, akan tetapi perlu penigkatan dan latihan secara berkelanjutan melihat ada sebagian kecil pemain berada dalam kategori cukup dan bahkan belum ada pemain yang mencapai kategori istimewa.

Perlu ditekankan bahwa penelitian lebih lanjut juga perlu dilakukan untuk bisa meningkatkan keterbatasan yang ada dalam penelitian ini. Misalnya perlu juga dijelaskan penggunaan jenis tes reaksi lainya, atau dengan profil sampel yang berbeda seperti atlet dari kategori junior, yang dapat memberikan data yang dapat berkontribusi untuk meningkatkan kualitas pelatihan, pembinaan prestasi, dan lain-lain. 


\section{SIMPULAN}

Penelitian ini telah menunjukkan analisis dan evaluasi tentang kecepatan reaksi yang dimiliki oleh pemain bola voli di Kelas Khusus Olahraga Yogyakarta. Dari data yang diperoleh pemain yang berada di kategori bagus sudah mencapai 63\%, akan tetapi perlu penigkatan dan latihan secara berkelanjutan melihat ada sebagian kecil pemain berada dalam kategori cukup dan bahkan belum ada pemain yang mencapai kategori istimewa. Analisis yang digunakan untuk mengukur waktu reaksi tentu perlu digunakan dalam merancang dan melaksanakan program latihan yang memiliki tujuan untuk terus meningkatkan kemampuan kecepatan reaksi yang dimiliki oleh atlet sebagai bentuk untuk terus mengembangkan dan mengoptimalkan performa mereka dalam permainan olahraga bola voli. Penelitian lebih lanjut perlu dilakukan untuk terus mengoptimalkan kaitanya dengan peningkatkan performa yang dimiliki oleh atlet.

\section{DAFTAR PUSTAKA}

Abreu, A. M., Macaluso, E., Azevedo, R. T., Cesari, P., Urgesi, C., \& Aglioti, S. M. (2012). Action anticipation beyond the action observation network: A functional magnetic resonance imaging study in expert basketball players. European Journal of Neuroscience, 35(10). https://doi.org/10.1111/j.1460-9568.2012.08104.x

Agostino, R., Currà, A., Soldati, G., Dinapoli, L., Chiacchiari, L., Modugno, N., Pierelli, F., \& Berardelli, A. (2004). Prolonged practice is of scarce benefit in improving motor performance in Parkinson's disease. Movement Disorders, 19(11). https://doi.org/10.1002/mds.20247

Akarsu, S., Çalişkan, E., \& Dane, Ş. (2009). Athletes have faster eye-hand visual reaction times and higher scores on visuospatial intelligence than nonathletes. Turkish Journal of Medical Sciences, 39(6). https://doi.org/10.3906/sag-0809-44

Akpinar, S., Devrilmez, E., \& Kirazci, S. (2012). Coincidence-anticipation timing requirements are different in racket sports. Perceptual and Motor Skills, 115(2). https://doi.org/10.2466/30.25.27.PMS.115.5.581-593

Atmaja, N. M. K., \& Tomoliyus, T. (2015). PENGARUH METODE LATIHAN DRILL DAN WAKTU REAKSI TERHADAP KETEPATAN DRIVE DALAM PERMAINAN TENIS MEJA. Jurnal Keolahragaan, 3(1). https://doi.org/10.21831/jk.v3i1.4969

Bamne, S. N., Fadia, A. D., \& Jadhav, A. V. (2011). Effect of colour and gender on human reaction time. In Indian Journal of Physiology and Pharmacology (Vol. 55, Issue 4).

Botwinick, J., \& Thompson, L. W. (1966). Premotor and motor components of reaction time. Journal of Experimental Psychology, 71(1). https://doi.org/10.1037/h0022634

Connor, J. D., Crowther, R. G., \& Sinclair, W. H. (2018). Effect of different evasion maneuvers on anticipation and visual behavior in elite rugby league players. Motor Control, 22(1). https://doi.org/10.1123/mc.2016-0034

Emre, A. K., \& Koçak, S. (2010). Coincidence-anticipation timing and reaction time in youth tennis and table tennis players. Perceptual and Motor Skills, 110(3). https://doi.org/10.2466/pms.110.3.879-887

Fananlampir, A. (2015). Tes dan Pengukuran dalam Olahraga. Andi Ofset.

Fischer, K. W., \& Bidell, T. R. (1998). Dynamic development of psychological structures in action and thought. In Handbook of child psychology: Volume 1. Theoretical models of human development.

Fujii, K., Shinya, M., Yamashita, D., Kouzaki, M., \& Oda, S. (2014). Anticipation by basketball defenders: An explanation based on the three-dimensional inverted pendulum model. European Journal of Sport Science, 14(6). https://doi.org/10.1080/17461391.2013.876104 
Gandhi, P. H., Gokhale, P. A., Mehta, H. B., \& Shah, C. J. (2013). A comparative study of simple auditory reaction time in blind (congenitally) and sighted subjects. Indian Journal of Psychological Medicine, 35(3). https://doi.org/10.4103/0253-7176.119486

Gardner, H., \& Hatch, T. (1989). Educational Implications of the Theory of Multiple Intelligences. Educational Researcher, 18(8). https://doi.org/10.3102/0013189X018008004

Gavkare, A. M. (2013). Auditory Reaction Time, Visual Reaction Time and Whole Body Reaction Time in Athletes. Medind.Nic.In, June.

Guadagnoll, M. A., \& Lee, T. D. (2004). Challenge Point: A Framework for Conceptualizing the Effects of Various Practice Conditions in Motor Learning. In Journal of Motor Behavior (Vol. 36, Issue 2). https://doi.org/10.3200/JMBR.36.2.212-224

Gülaç, M., Devrilmez, E., Kirazcı, S., \& Yüksel, O. (2017). Investigation of the Anticipation Time in Forehand and Backhand Strokes of Badminton Players. Journal of Education and Training Studies, 5(13). https://doi.org/10.11114/jets.v5i13.2876

Gutierrez-Davila, M., Rojas, F. J., Ortega, M., Campos, J., \& Parraga, J. (2011). Anticipatory strategies of team-handball goalkeepers. Journal of Sports Sciences, 29(12). https://doi.org/10.1080/02640414.2011.591421

Hülsdünker, T., Strüder, H. K., \& Mierau, A. (2018). The athletes' visuomotor system-Cortical processes contributing to faster visuomotor reactions. In European Journal of Sport Science (Vol. 18, Issue 7). https://doi.org/10.1080/17461391.2018.1468484

Kamijo, K., Pontifex, M. B., Khan, N. A., Raine, L. B., Scudder, M. R., Drollette, E. S., Evans, E. M., Castelli, D. M., \& Hillman, C. H. (2014). The negative association of childhood obesity to cognitive control of action monitoring. Cerebral Cortex, 24(3). https://doi.org/10.1093/cercor/bhs349

Kim, J. H., Lee, K. K., Kong, S. J., An, K. O., Jeong, J. H., \& Lee, Y. S. (2014). Effect of anticipation on lower extremity biomechanics during side-and cross-cutting maneuvers in young soccer players. American Journal of Sports Medicine, 42(8). https://doi.org/10.1177/0363546514531578

Kioumourtzoglou, E., Kourtessis, T., Michalopoulou, M., \& Derri, V. (1998). Differences in several perceptual abilities between experts and novices in basketball, volleyball and water-polo. Perceptual and Motor Skills, 86(3 PART 1). https://doi.org/10.2466/pms.1998.86.3.899

Loffing, F., \& Hagemann, N. (2014). Skill differences in visual anticipation of type of throw in teamhandball penalties. Psychology of Sport and Exercise, 15(3). https://doi.org/10.1016/j.psychsport.2014.01.006

Lotério Barcelos, J., Pontes Morales, A., Nascimento Maciel, R., dos Anjos Azevedo, M. M., \& Furtado da Silva, V. (2009). Time of practice: a comparative study of the motor reaction time among volleyball players. Fitness \& Performance Journal, 8(2). https://doi.org/10.3900/fpj.8.2.103.e

Luce, R. D. (2008). Response Times: Their Role in Inferring Elementary Mental Organization. In Response Times: Their Role in Inferring Elementary Mental Organization. https://doi.org/10.1093/acprof:oso/9780195070019.001.0001

Maciel, R. N., Morales, A., Barcelos, J., Nunes, W., Azevedo, M. M., \& Furtado, V. (2009). Relation between reaction time and specific function in volleyball players. Fitness \& Performance Journal, 8(6). https://doi.org/10.3900/fpj.8.6.395.e

Millán-Sánchez, A., Rábago, J. C. M., \& Espa, A. U. (2019). The middle blocker in volleyball: A systematic review. Journal of Human Sport and Exercise, 14(1). https://doi.org/10.14198/jhse.2019.141.03

Moradi, A., \& Esmaeilzadeh, S. (2015). Association between reaction time, speed and agility in schoolboys. Sport Sciences for Health, 11(3). https://doi.org/10.1007/s11332-015-0230-4 
Mori, S., Ohtani, Y., \& Imanaka, K. (2002). Reaction times and anticipatory skills of karate athletes. Human Movement Science, 21(2). https://doi.org/10.1016/S0167-9457(02)00103-3

Nakamoto, H., \& Mori, S. (2012). Experts in fast-ball sports reduce anticipation timing cost by developing inhibitory control. Brain and Cognition, 80(1). https://doi.org/10.1016/j.bandc.2012.04.004

Nasriani, A., \& Mardela, R. (2019). Kecepatan Reaksi Dan Koordinasi Mata-Tangan Berhubungan Dengan Kemampuan Smash Bolavoli. Jurnal Patriot, Universitas Negeri Padang2, 1(3).

Nurhasan. (2007). tes dan pengukuran pendidikan olahraga. In Time (Vol. 6, Issue 3). FPOK UPI.

Nuri, L., Shadmehr, A., Ghotbi, N., \& Attarbashi Moghadam, B. (2013). Reaction time and anticipatory skill of athletes in open and closed skill-dominated sport. European Journal of Sport Science, 13(5). https://doi.org/10.1080/17461391.2012.738712

Piras, A., Lobietti, R., \& Squatrito, S. (2014). Response time, visual search strategy, and anticipatory skills in volleyball players. Journal of Ophthalmology, 2014. https://doi.org/10.1155/2014/189268

Proctor, R. W., \& Dutta, A. (1995). Skill acquisition and human performance. In Skill acquisition and human performance.

Rao, S. L., Gangadhar, B. N., Keshavan, M. S., Hegde, A. S., \& Nardev, G. (1985). Reaction time deficits in post traumatic syndrome. Indian Journal of Psychiatry, 27(1).

Rojas-Valverde, D. (2021). Potential Role of Cannabidiol on Sports Recovery: A Narrative Review. In Frontiers in Physiology (Vol. 12). https://doi.org/10.3389/fphys.2021.722550

Saygin, O., Goral, K., \& Ceylan, H. I. (2016). An Examination of the Coincidence Anticipation Performance of Soccer Players according to their Playing Positions and Different Stimulus Speeds. Sport Journal, August 2016.

Schorer, J., Rienhoff, R., Fischer, L., \& Baker, J. (2013). Foveal and peripheral fields of vision influences perceptual skill in anticipating opponents' attacking position in volleyball. Applied Psychophysiology Biofeedback, 38(3). https://doi.org/10.1007/s10484-013-9224-7

Smith, A. P., Brice, C., Leach, A., Tiley, M., \& Williamson, S. (2004). Effects of upper respiratory tract illnesses in a working population. Ergonomics, 47(4). https://doi.org/10.1080/0014013032000157887

Solanki, J., Joshi, N., Shah, C., HB, M., \& PA, G. (2012). A Study of Correlation between Auditory and Visual Reaction Time in Healthy Adults. International Journal of Medicine and Public Health, 2(2). https://doi.org/10.5530/ijmedph.2.2.8

Spencer, S. V., Hawk, L. W., Richards, J. B., Shiels, K., Pelham, W. E., \& Waxmonsky, J. G. (2009). Stimulant treatment reduces lapses in attention among children with ADHD: The effects of methylphenidate on intra-individual response time distributions. Journal of Abnormal Child Psychology, 37(6). https://doi.org/10.1007/s10802-009-9316-2

Suharsimi, A. (2013). Dasar-Dasar Evaluasi Pendidikan. In Jakarta: Bumi Aksara.

Takeyama, T., Hirose, N., \& Mori, S. (2011). Temporal change in response bias observed in expert anticipation of volleyball spikes. Proceedings of Fechner Day, 19-24.

Tan, Ü. (2007). The psychomotor theory of human mind. In International Journal of Neuroscience (Vol. 117, Issue 8). https://doi.org/10.1080/00207450600934556

Tomporowski, P. D. (2003). Effects of acute bouts of exercise on cognition. Acta Psychologica, 112(3). https://doi.org/10.1016/S0001-6918(02)00134-8

Zhannisa, U. H., \& Sugiyanto, F. (2015). MODEL TES FISIK PENCARIAN BAKAT OLAHRAGA BULUTANGKIS USIA DI BAWAH 11 TAHUN DI DIY. Jurnal Keolahragaan. https://doi.org/10.21831/jk.v3i1.4974 
Fauzi, Riky Dwihandaka, Okky Indera Pamungkas, Muhamad Nanang Solikhin

Zhou, Y. (2018). Visual search, prediction ability and brain neural mechanisms of different of female volleyball players. NeuroQuantology, 16(6). https://doi.org/10.14704/nq.2018.16.6.1682

Zwierko, T., Osiński, W., Lubiński, W., Czepita, D., \& Florkiewicz, B. (2010). Speed of visual sensorimotor processes and conductivity of visual pathway in volleyball players. Journal of Human Kinetics, 23(1). https://doi.org/10.2478/v10078-010-0003-8 